Agro-Science Journal of Tropical Agriculture, Food, Environment and Extension Volume 21 Number 1 (January 2022) pp. $34-38$

ISSN 1119-7455

\title{
MUSHROOM CONSUMPTION PATTERN AMONG RESIDENTS OF IBADAN METROPOLIS IN OYO STATE, NIGERIA
}

\author{
*Oguntoye T.O., Adesope A.A., Fatoki O.A., Arowolo O.V., Olawale O.O. and Oyetoki A.O. \\ Department of Forest Economics \& Extension, \\ Forestry Research Institute of Nigeria, Ibadan, Nigeria \\ *Corresponding author's email: yemmytoye@yahoo.com; Tel.: +234803-482-0771
}

\begin{abstract}
The study examined the consumption of mushroom among the residents of Ibadan metropolis in Oyo State Nigeria. A two-stage random sampling procedure was used to select a total of 250 respondents. A structured questionnaire was used to obtain information from the selected respondents. Descriptive statistics and regression analysis were used in analyzing the data. The results showed that majority (66\%) of the respondents were within the age range 31-60 years. The majority (68.8\%) of the respondents were married and possessed tertiary education (52\%). Most (87.2\%) of the respondents ate mushrooms but $50.8 \%$ of the respondents ate mushroom occasionally. Majority (70\%) of the respondents indicated that mushroom was not readily available. Most (84\%) of them preferred mushroom to other sources of protein. Nutritive value (1 ${ }^{\text {st }}$ ) and organoleptic characteristics $\left(2^{\text {nd }}\right)$ were the main reasons for consuming mushroom. The regression analysis showed that age $(t=2.099, p=0.031)$, educational level $(t=2.310, p=0.015)$, monthly income $(t=5.037, p=0.000)$, household size $(t=4.260, p=0.001)$, mushroom availability $(t=2.740, p=0.000)$ and awareness of benefits of mushroom $(t=2.710, p=0.000)$ significantly predicted its consumption. The major constraints to mushroom consumption in the study area included seasonal production (92.0\%), poor shelf life (76.0\%), and financial constraints (58.8\%). Based on the findings, the study therefore recommends that for all-year-round availability, mushroom farming on the domestication should be encouraged. Intensified training and awareness campaign should be provided to the populace on domestication of mushroom by the Forestry Research Institute of Nigeria.
\end{abstract}

Key words: mushroom, consumption, regression analysis, Ibadan metropolis

\section{INTRODUCTION}

Mushrooms are the edible fleshy fruiting bodies of certain fungi which may be gathered in the wild or grown under cultivation. The cap and stem that we commonly eat is just the fruiting body. (Yehuala, 2012). They belong to a separate kingdom called Fungus, which is distinct from plant and animal kingdoms. Fungi differ from plants in the way they obtain their nutrients, they do not have chlorophyll and so do not manufacture their own foods. They possess microscopic spores, which serve as a means of reproduction (Ndem and Oku, 2016). Chang and Philop (2004) stated that mushrooms are widely distributed in temperate and tropical regions. Mushrooms are of different kinds: the edible mushrooms and inedible mushrooms. Edible mushrooms have medicinal value unlike non-edible.

Mushroom is considered to be a complete health food suitable for all age groups. Mushrooms have long been valued as high-quality food with a pleasant flavour, taste, appealing texture nutrition by different societies throughout the world (Muruke et al., 2002). They are now known to be good sources of protein, providing an alternative protein source to vegetarians. According to Yehuala (2012), mushrooms usually contain $20-30 \%$ protein (about $3 \%$ on fresh weight basis) which is higher than that of most vegetables. Mushroom protein is superior to vegetable protein. The proteins have high digestibility. They also contain several vitamins such as Vitamin A (Retinol), Vitamin B (Thiamin (B1)), (Riboflavin (B2)), Nicotinic acid (Niacin), Pantothenic acid (B6), Vitamin C (Ascorbic acid), Vitamin D (Calciferol) and Vitamin $\mathrm{K}$ and other inorganic substances like Phosphorus, Calcium, Potash, Zinc, Copper, Iron and other enzymes. Mushrooms are also rich in essential amino acids that cannot be synthesized by our body as well as the most commonly occurring non-essential amino acids.

Edible mushrooms commonly have low lipid levels with a higher proportion of polyunsaturated fatty acids. All these result in low calorific yield from mushroom foods. Mushrooms do not have cholesterol. Instead, they have ergosterol that acts as a precursor for Vitamin D synthesis in the human body. Cholesterol and the sterol known to be dreaded for the heart are absent in mushrooms (Chaube, cited in Yehuala, 2012). Fresh mushrooms contain a relatively large amount of carbohydrate (4-5\%), fiber and significant amounts of phosphorous,

Please cite as: Oguntoye T.O., Adesope A.A., Fatoki O.A., Arowolo O.V., Olawale O.O. and Oyetoki A.O. (2022). Mushroom consumption pattern among residents of Ibadan metropolis in Oyo State, Nigeria. Agro-Science, 21 (1), 34-38. DOI: https://dx.doi.org/10.4314/as.v21i1.6 
sodium and potassium but lesser amounts of calcium and iron (Bains and Tripathi, 2016). They have been prized as a delicacy for more than 2000 years now (Quimio et al., 1990; Buah et al., 2010). The earliest and comprehensive account of mushrooms cultivation in France could be found in Adinya et al. (2012).

Food consumption patterns can be defined as the recognizable ways of eating foods. Rural dwellers tend to adhere to their old eating patterns rather than venturing to seek new and more proper eating habits. In order to maintain healthful diets, Jama (2002) asserts that a variety and balance of foods from all food groups and moderate consumption of all food items is very important. The importance of food in any country cannot be overemphasized. There is in fact a growing concern in the world today that food production increases are not keeping pace with the phenomenal increase in population in developing countries such as Nigeria. Specifically, activities in production of food (including livestock and fishing), processing and marketing account for approximately $80 \%$ by value of Nigeria's total agricultural output.

Despite the apparent significance of food to the Nigerian agricultural economy, the food intake in the country has been found to be inadequate not only in terms of quantity but also in terms of quality. FAO revealed that the diet of an average Nigerian contains 33\% less than the recommended protein requirement, showing that the average Nigerian diet is deficient of other basic nutrients like iron, lysine and niacin (FAO, 2004). These data for Nigeria also showed a $6.7 \%$ rate of undernourishment in 2013, which rose to $11.5 \%$ in 2017 (FAOSTAT, 2020). The Recommended Dietary Allowance (RDA) for protein consumption has been estimated by the WHO at $0.8 \mathrm{~g} / \mathrm{kg} /$ day (FAO, 2004). This amounts to $56 \mathrm{~g} / \mathrm{capita} /$ day or $20.4 \mathrm{~kg} /$ capita/year for an adult weighing $63.5 \mathrm{~kg}$. It is important to note that the minimum recommended level, or "recommended intake", is not necessarily the ideal level of protein intake, but the one below which health conditions deteriorate. For instance, the FAO recommendation for daily protein consumption is $60 \mathrm{~g}$ per person, of which $30 \mathrm{~g}$ is expected to be from an animal source. Data from the FAO show that the average per capita protein intake for Nigeria in 2013 was $63.8 \mathrm{~g}$, of which only $10 \mathrm{~g}$ came from animal sources. This is in contrast with figures from developed countries, where the average per capita protein intake was over $80 \mathrm{~g}$, with more than $55 \mathrm{~g}$ of animal protein (FAOSTAT, 2013). This is as a result of poverty in Nigeria thus leading to an increase in food nutritional inadequacy when Nigerians could not afford the required nutrition including protein. Several studies have extensively elucidated the consumption pattern of other protein sources in Nigeria but neglecting the mushroom consumption.

Mushroom, a nutritious food containing quantities of essential amino acids with several health and nutritional benefits which can fill the wide gap and minimize protein malnutrition and by so doing sustain life should be available. In view of the above, this study examined the pattern of mushroom consumption among the inhabitants of Ibadan metropolis. The research objectives were to (i) describe the socioeconomic characteristics of the respondents, (ii) examine consumers acceptability of mushroom, (iii) identify reasons for consuming mushroom, (iv) examine the level of awareness of mushroom consumption, (v) identify the determinants of mushroom consumption, and (v) to identify the constraints associated with mushroom consumption.

\section{MATERIALS AND METHODS}

The study was carried out in Ibadan metropolis, the capital of Oyo State in Southwest Nigeria. Ibadan metropolis is made up of eleven Local Governments Areas (LGAs) consisting of five in urban area and six in semi-urban area. For the purpose of this study, the urban area was considered and they are Ibadan North, Ibadan Southeast, Ibadan Southwest, Ibadan Northeast and Ibadan Northwest. As at 2015, the population of Ibadan was 3.1 million, and it was estimated that by 2019 the population would rise to 3.7 million (United Nation Development Programme, 2019). The economic activities of Ibadan include agriculture, commerce, handcrafts, manufacturing and service industries. Ibadan has a tropical wet and dry climate with a lengthy wet season and temperature varying between 21.9 and $37.3^{\circ} \mathrm{C}$ throughout the year. Ibadan is a forest site containing several ranges of hills, varying in elevation covered by the rain forest; the composition is basically the large tall crowned trees mixed with thick undergrowth. A greater percentage is grass and woodland soils, covered by loamy soils. Like most cities in Nigeria, Ibadan is faced with issue of poor drainage systems and water tight structures which results in flooding. Houses are constructed directly on drain channels and that results in blockade of storm drains, in overflow and flooding of streets (NPC, 2006; Adelekan, 2016).

\section{Data Collection}

A structured questionnaire was used to elicit information from the respondents. Two-stage sampling procedure was adopted for the study. The first stage was taking five LGAs as clusters from the 11 LGAs (Ibadan North, Ibadan Northwest, and Ibadan Northeast, Ibadan Southeast and Ibadan Southwest). In the second stage, 50 respondents were randomly selected from each of the selected LGAs. In all a total of 250 respondents were interviewed.

\section{Data Analysis}

Descriptive analysis was used to analyze the socioeconomic characteristics of the respondents, their acceptability of mushroom, and the constraints associated with mushroom consumption in the study area, while multiple regression was used to analyze the determinants of mushroom consumption in the study. The model is specified as follows:

$$
\mathrm{C}=\left(\mathrm{X}_{1}, \mathrm{X}_{2}, \mathrm{X}_{3}, \mathrm{X}_{4}, \mathrm{X}_{5}, \mathrm{X}_{6}, \mathrm{X}_{7}, \mathrm{X}_{8}, \mathrm{X}_{9}, \mathrm{e}\right) \text {; }
$$


where $\mathrm{C}$ is mushroom consumption (quantity/grams), $\mathrm{X}_{1}$ is age (years), $\mathrm{X}_{2}$ is educational level (years), $\mathrm{X}_{3}$ is monthly income ( $), X_{4}$ is household size (number), $\mathrm{X}_{5}$ is availability of mushroom ( $\mathrm{Yes}=1$, No $=0), X_{6}$ is price of mushroom ( $/$ gram), $X_{7}$ is nutritive value of mushroom ( $\mathrm{Yes}=1, \mathrm{No}=0), \mathrm{X}_{8}$ is taste of mushroom (Yes $=1, \mathrm{No}=0), \mathrm{X}_{9}$ is marital status (married $=1$, otherwise $=0$ ), and e is error term.

\section{RESULTS AND DISCUSSION}

Socioeconomic Characteristics of the Respondents The socioeconomic characteristics of the respondents revealed that $60 \%$ of the respondents in the study area were females (Table 1). This indicates that females are more than males and this has important effect on the consumption of mushroom because females are in most cases decision makers in household consumption according to Adeoye and Balogun (2012). About $68.8 \%$ of the respondents were married, $24 \%$ were single, $4.8 \%$ were widowed and $2.4 \%$ were divorced. Majority $66 \%$ of the respondents were in the age range $31-60,18 \%$ were above 61 years old, only $16 \%$ were below 30 years old. Most (54\%) of the respondents had 6-10 household size, $44 \%$ had less than 5 members in their household and only $2 \%$ had above 10 members in their household. This result is in contrast with Pollack and Wales (2003) that consumption rate is a function of family size. Majority (52\%) of the respondents had tertiary education, $20 \%$ had secondary education and only $8.8 \%$ had no formal education. Majority of the respondents had one form of formal education or the other; so, most of them could read and write. This result aligned with Olagoke (2003) belief of educational level affecting food consumption patterns and such effect depends more on the nutritive values attached to the food rather than on the social values. About $42 \%$ were government employee (civil servant), $24 \%$ were traders, $22.8 \%$ were artisan and only $11.2 \%$ were students. Majority $(40 \%)$ of the respondents earned income between 50,001 and 100,000 Naira, 28\% earned income above 100, 000 Naira and only $8 \%$ earned income less than 10,000 Naira.

\section{Acceptability and Preference for Mushroom}

The results in Table 2 show the consumer's acceptability and preference for mushroom. Majority $(87.2 \%)$ of the respondents ate mushroom. This is in agreement with Adedokun and Okomadu (2017) who revealed that a large proportion of respondents eat mushroom. Most (42\%) of the respondents in the study area consume the wild mushroom. This corroborates the studies of Adedokun and Okomadu (2017) which reported that wild mushroom is mostly consumed. Majority of the respondents $(70 \%)$ said mushroom is not readily available. About $50.8 \%$ of the respondents consume mushroom occasionally. This agrees with Adedokun and Okomadu (2017) who reported that only a few consume it year-round.
Table 1: Socio-economic characteristics of the respondents $(n=250)$

\begin{tabular}{|c|c|c|c|}
\hline \multicolumn{2}{|l|}{ Variables } & \multirow{2}{*}{$\begin{array}{l}\text { Frequency } \\
100\end{array}$} & \multirow{3}{*}{$\begin{array}{l}\text { Percentage } \\
40 \\
60\end{array}$} \\
\hline Gender & Male & & \\
\hline & Female & 150 & \\
\hline \multirow[t]{4}{*}{ Marital Status } & Single & 60 & 24 \\
\hline & Married & 172 & 68.8 \\
\hline & Widowed & 12 & 4.8 \\
\hline & Divorced & 06 & 2.4 \\
\hline \multirow[t]{3}{*}{ Age } & & 40 & 16 \\
\hline & $31-60$ & 165 & 66 \\
\hline & $\geq 61$ & 65 & 18 \\
\hline \multirow[t]{3}{*}{ Household Size } & $\leq 5$ & 110 & 44 \\
\hline & $6-10$ & 135 & 54 \\
\hline & $\geq 11$ & 05 & 02 \\
\hline \multicolumn{4}{|l|}{ Education level } \\
\hline \multicolumn{2}{|c|}{ No formal Education } & 22 & 8.8 \\
\hline \multicolumn{2}{|c|}{ Primary Education } & 48 & 19.2 \\
\hline \multicolumn{2}{|c|}{ Secondary Education } & 50 & 20 \\
\hline \multicolumn{2}{|c|}{ Tertiary Education } & 130 & 52 \\
\hline \multicolumn{4}{|c|}{ Occupation } \\
\hline \multicolumn{2}{|l|}{ Students } & 28 & 11.2 \\
\hline \multicolumn{2}{|l|}{ Civil Servant } & 105 & 42 \\
\hline \multicolumn{2}{|l|}{ Artisan } & 57 & 22.8 \\
\hline \multirow{2}{*}{\multicolumn{2}{|c|}{$\begin{array}{l}\text { Trading } \\
\text { Monthly Income (Naira) }\end{array}$}} & 60 & 24 \\
\hline & & & \\
\hline \multicolumn{2}{|c|}{$\leq 10,000$} & 20 & 08 \\
\hline \multicolumn{2}{|l|}{$10,001-50,000$} & 60 & 24 \\
\hline \multirow{2}{*}{\multicolumn{2}{|c|}{$\begin{array}{l}50,001-100,000 \\
\geq 100,000\end{array}$}} & 100 & 40 \\
\hline & & 70 & 28 \\
\hline \multicolumn{2}{|l|}{ Total } & 250 & 100 \\
\hline
\end{tabular}

Source: Field Survey, 2020

Table 2: Consumers acceptability and preference for mushroom $(n=250)$

\begin{tabular}{lll} 
Variables & Frequency & Percentage \\
\hline Do you eat Mushroom & & \\
No & 32 & 12.8 \\
Yes & 218 & 87.2 \\
Total & 250 & 100 \\
Types of mushroom consumed & & \\
Wild mushroom & 105 & 42 \\
Cultivated & 95 & 38 \\
Both & 18 & 7.2 \\
None & 32 & 12.8 \\
Total & 250 & 100 \\
Readily Available & & \\
No & 175 & 70 \\
Yes & 75 & 30 \\
Total & 250 & 100 \\
How often do you consume & & \\
mushroom? & 0 & 0 \\
Weekly & 15 & 6 \\
Fortnightly & 108 & 43.2 \\
Monthly & 127 & 50.8 \\
Occasionally & 250 & 100 \\
Total & & \\
How much do you spend on & & \\
mushroom consumption? & & \\
(Naira) & 12 & 4.8 \\
<500 & 95 & 38 \\
501-1000 & 102 & 40.8 \\
1001-2000 & 41 & 16.4 \\
>2001 & 250 & 100 \\
Total & & \\
Do you prefer mushroom to \\
other sources of protein?
\end{tabular}


Also $40.8 \%$ of the respondents spent between 1000 and 2000 Naira per month on mushroom. Most $(84 \%)$ of the respondents prefer mushroom to other sources of protein. This could be due to the fact that mushrooms were so rich in nutrient content that meat and vegetable can provide to human diet (Adejo and Ademu 2018). This implies that mushroom can contribute to the human nutrition. This is in agreement with Oyedele et al. (2018) who affirmed that mushroom production can contribute significantly to household food and nutrition.

\section{Reasons for Consuming Mushroom}

The results in Table 3 show the reasons for consuming mushroom in the study area. Majority $(88.8 \%$ and $87.2 \%)$ of the respondents consume mushroom because of its nutritive value and organoleptic characteristics ranked $1^{\text {st }}$ and $2^{\text {nd }}$. This corroborates with Adejo and Ademu (2018) study which revealed that majority of the respondents consume mushroom because of its nutritive and organoleptic characteristics. Most $(80 \%)$ of the respondents consume mushroom because of their income level ranked $3^{\text {rd }}$. About $75.2 \%$ of respondents consume mushroom because of the satisfaction derived from mushroom ranked $4^{\text {th }}$. Furthermore, about $68 \%$ of the respondents consume mushroom because of its freshness ranked $5^{\text {th }}$, while most $(60 \%)$ of the respondents consume mushroom because it is a close substitute to meat and fish ranked $6^{\text {th }}$. This is in agreement with Adejo and Ademu (2018) that respondents consume mushroom because of its close substitute to meat.

Table 3: Reasons for consuming mushroom $(n=250)$

\begin{tabular}{l|c|c|c}
\hline $\begin{array}{l}\text { Reasons for } \\
\text { consuming mushroom }\end{array}$ & $\begin{array}{c}\text { Frequ- } \\
\text { ency }\end{array}$ & $\begin{array}{c}\text { Percent- } \\
\text { age }\end{array}$ & Rank \\
\hline A close substitute to & 150 & 60 & $6^{\text {th }}$ \\
meat and fish & 170 & 68 & $5^{\text {th }}$ \\
Freshness & 218 & 87.2 & $2^{\text {nd }}$ \\
Organoleptic characteristics & 222 & 88.8 & $1^{\text {st }}$ \\
Nutritive value & 188 & 75.2 & $4^{\text {th }}$ \\
Satisfaction & 200 & 80 & $3^{\text {rd }}$ \\
Income & & &
\end{tabular}

Source: Field Survey, 2020

\author{
Awareness of Mushroom Consumption Benefits \\ in the Study Area
}

The results in Table 4 show the awareness of mushroom consumption benefits in the study area. $89.6 \%, 82.2 \%, 80.8 \%, 79.2 \%, 76.4 \%, 75.2 \%$ and $62 \%$ of the respondents are aware of mushroom lowcalorie content, anti-aging properties, cancer prevention, helps in the digestive system, heart support, strengthens immunity and nutritive value respectively. Using mean score to rank the awareness of mushroom consumption benefit as indicated by the respondents' nutritive value ranked $1^{\text {st }}(1.52)$; heart benefits ranked $2^{\text {nd }}(1.37)$ and lowcalorie food ranked $7^{\text {th }}(1.12)$.

\section{Determinants of Mushroom Consumption}

Table 5 shows the regression results of factors determining mushroom consumption in the study area. Age of the respondent was positively related to the quantity of mushroom consumed and significant at 5\% probability level. This implies that the older the consumer becomes, the more the quantity of mushroom consumed. This variable is in conformity with a priori expectation, that mushroom is a healthy protein and old people are safe to eat more of it. This could be due to the fact that mushroom was so rich in nutrient content that meat and vegetable can provide to human diet. This is in agreement with the studies of Adejo and Ademu (2018) who reported that an increase in age increases the probability of the respondents to consume mushroom. Education level was also positive and significant at $p \leq 0.05$. This implies that an increase in education level increases the probability of the respondents to consume mushroom, a phenomenon that is driven by increased knowledge of benefits of mushroom consumption. Monthly income, availability of mushroom and awareness of mushroom benefits were found to be positive and significant at $p \leq 0.011$. This implies that the probability for mushroom consumption among the respondents increases with monthly income, availability and awareness of mushroom benefits. This corroborates with Adejo and Ademu (2018) who stated that household who are aware of mushroom benefits tends to consume it more than households who are not.

Table 4: Awareness of mushroom consumption benefits $(n=250)$

\begin{tabular}{|c|c|c|c|c|c|}
\hline Awareness of mushroom consumption benefit & Aware & Unaware & Undecided & Mean & Ranking \\
\hline Mushroom has nutritive value & $155(62)$ & $60(24)$ & $35(14)$ & 1.52 & $1^{\text {st }}$ \\
\hline Mushroom is good for the heart & $191(76.4)$ & $28(11.2)$ & $32(12.8)$ & 1.37 & $2^{\text {nd }}$ \\
\hline Mushroom regulates the digestive system & $198(79.2)$ & $27(10.8)$ & $25(10)$ & 1.31 & $3^{\text {rd }}$ \\
\hline Mushroom strengthens immunity & $188(75.2)$ & $50(20)$ & $11(4.4)$ & 1.28 & $4^{\text {th }}$ \\
\hline Mushroom has anti-aging properties & $207(82.2)$ & $33(13.2)$ & $10(4)$ & 1.17 & $5^{\text {th }}$ \\
\hline Mushroom helps in prevention of cancer & $202(80.8)$ & $32(12.8)$ & $06(2.4)$ & 1.14 & $6^{\text {th }}$ \\
\hline Mushroom is a low-calorie food & $224(89.6)$ & $21(8.4)$ & $05(2)$ & 1.12 & $7^{\text {th }}$ \\
\hline
\end{tabular}

Figures in parentheses are percentages. Source: Field Survey, 2020 
Table 5: Determinants of mushroom consumption

\begin{tabular}{|c|c|c|c|}
\hline Variable & $\begin{array}{c}\text { Coeffi- } \\
\text { cient }\end{array}$ & $\begin{array}{c}\text { Std. } \\
\text { Error }\end{array}$ & t-value \\
\hline Age (years) & 0.050 & 0.024 & $2.099 * *$ \\
\hline Education level (years) & 0.018 & 0.008 & $2.310^{* *}$ \\
\hline Monthly income ( & 0.050 & 0.010 & $5.037 * * *$ \\
\hline Household size (number) & -1.909 & 0.448 & $-4.260 * * *$ \\
\hline Availability of mushroom & 1.989 & 0.726 & $2.740 * * *$ \\
\hline Mushroom benefits awareness & s 0.073 & 0.027 & $2.710 * * *$ \\
\hline Taste & -0.013 & 0.025 & -0.520 \\
\hline Marital status & -0.010 & 0.011 & -0.909 \\
\hline Constant & 2.466 & 1.507 & 1.64 \\
\hline $\mathrm{R}^{2}$ & 0.631 & & \\
\hline \multicolumn{4}{|c|}{$\begin{array}{l}\text { Source: Author's Computation, } 2020 \\
\text { Note: ***means significant at } 1 \%, * * \mathrm{n}\end{array}$} \\
\hline \multicolumn{4}{|c|}{$\begin{array}{l}\text { Table 6: Constraints associated with mushroom } \\
\text { consumption }(n=250)\end{array}$} \\
\hline Variables & & $\begin{array}{c}\text { *Frequ- } \\
\text { ency }\end{array}$ & $\begin{array}{c}\text { Percent- } \\
\text { age }\end{array}$ \\
\hline Seasonal Unavailability & & 230 & 92 \\
\hline Lack of knowledge on prepar & ration & 45 & 18 \\
\hline Financial constraint (Income) & & 147 & 58.8 \\
\hline Poor shelf life & & 190 & 76 \\
\hline Taste & & 19 & 7.6 \\
\hline Source & & 120 & 48 \\
\hline Allergy in consumption & & 86 & 34.4 \\
\hline
\end{tabular}

\section{Constraints to Mushroom Consumption}

Table 6 shows the constraints to mushroom consumption. Most (92\%) of the respondents were faced with seasonal availability. This is in agreement with Adedokun and Okomadu studies who reported that seasonal availability was a major constraint in mushroom consumption. Also, 76\% indicated poor shelf life of mushroom as a constraint while $58.8 \%$ indicated, financial constraint as a constraint. Only few (7.6\%) respondents indicated taste as a constraint in mushroom consumption.

\section{CONCLUSION AND \\ RECOMMENDATIONS}

The study found that majority of the respondents in Ibadan metropolis were married. More than half of them consumed mushroom occasionally mainly because of its unavailability. Most of them consumed mushroom because of its nutritive and organoleptic characteristics. Majority of the respondents were aware of its nutritive and medicinal values. Age, educational level, monthly income, household size, availability of mushroom and awareness of mushroom benefits were determinants of mushroom consumption in the study area. The major constraints to mushroom consumption in the area were seasonal availability, poor shelf life and financial constraints. This study thus concluded that for all-year-round availability, mushroom farming and domestication should be encouraged to sustain production. Also, intensified training and awareness should be provided to the populace on domestication of mushroom by Forestry Research Institute of Nigeria (FRIN). Based on its poor shelf life, there is the need for awareness and training of communities on value addition including soaking, drying, boiling, salting and proper packaging.

\section{References}

Adedokun O.M. and Okomadu C.A. (2017). Wild and domesticated mushroom consumption in Nigeria. African Crop Sci. J., 25, 123. 10.4314/acsj.v25i1.9

Adejo P.E. and Ademu H. (2018). Attitude of rural farming household towards the consumption of edible mushrooms in Dekina Local Government Area, Kogi State, Nigeria. Nutri Food Sci. Int. J., 5 (3), 555-661. DOI: 10.19080/NFSIJ.2018.05.555661

Adelekan I.O. (2016). Ibadan Diagnostic Report, Working paper No. 4 Urban Ark Ibadan University

Adeoye I.B. and Balogun O.L. (2012). Consumer preference for watermelon varieties in urban environment of Ibadan Metropolis, Oyo State, Nigeria. Global Sci. Books, 6 (1), 93-96

Adinya I.B., Ijoma J.U., Enil I., Ewona G., Anyorah C.N. and Ogar N.E. (2012). Analysis of edible mushroom marketing in three villages in central Cross River State, Nigeria. Global J. Agric. Sci., 11 (2), 73-80

Bains A. and Tripathi A. (2016). Antibacterial activity and phyto-chemical screening of wild edible mushroom Pleurotus ostreatus collected from Himachal Pradesh. Int. J. Adv. Res., 4 (4), 467-474

Buah, J.N., Van der Puije G.C., Bediako E.A., Abole E.A. and Showemimo F. (2010). The growth and yield performance of oyster mushroom (Pleurotus ostreatus) on different substrates. Biotechnol., 9, 338-342

Chang S-T. and Philop G.M. (2004). Mushrooms: Cultivation, Nutritional Value, Medicinal Effect and Environmental Impact. Boca Raton, Florida: CR Press

Chaube H.S. (1995). Nutritional and Medicinal Value of Mushroom Production Technology, University of Agriculture \& Technology, India pp. 1-6

FAO (2004). Human Energy Requirements. Report of a Joint FAO/WHO/UNU Expert Consultation. World Health Organ. Tech. Rep. Ser., 1, 35-50

FAOSTAT (2013). FAO Statistical (FAOSTAT) Database. FAO of the United Nations, Rome, Italy

FAOSTAT (2020). FAO Statistical (FAOSTAT) Database. Accessed 05/03/2020 http://www.fao.org/faostat/ en/\#data

Jama P.P. (2002). A healthy diet. J. Am. Med. Assoc., 283, $2198-2000$

Muruke M., Kivaisi A., Magingo F and Danell E (2002). Identification of mushroom mycelia using DNA techniques. Tanzania J. Sci., 28, 115-128

Ndem J.U. and Oku M.O. (2016). Mushroom production for food security in Nigeria. Food Sci. Qual. Manage., $48,44-50$

NPC (2006). Population and Housing Census of Nigeria, National Population Commission (NPC), Abuja, Nigeria

Olagoke P.E. (2003). Food Consumption Patterns in the University of Ile-Ife. BSc Thesis. Dept. of Agricultural Economics, University of Ile-Ife Oyo State Nigeria

Oyedele O.A., Adeosun M.V. and Koyenikan O.O. (2018). Low cost production of mushroom using agricultural waste in a controlled environment for economic advancement. Int. J. Waste Resour., 8, 329. DOI: $10.4172 / 2252-5211.1000329$

Pollack R.A. and Wales J.J. (2003). Demographic variables in demand analysis. Econometrical, 49, 533-538

Quimio T.H., Chang S.T. and Roysee D.J. (1990). Technical Guidelines for Mushroom Growing in the Tropics (FAO Plant Production and Protection Papers). FAO of the United Nations, Rome, Italy, p. 106

Yehuala K. (2012). Contribution of small scale mushroom production for food security in the Amhara region, Ethiopia. In: Experience Sharing and Revitalization Workshop of Amhara Region Food Security Network. 26-27 August. Bahir Dar, Ethiopia. 28 pp.

United Nation Development programme (2019). World Population Review. worldpopulationreview.com/ countries/nigeria-population 